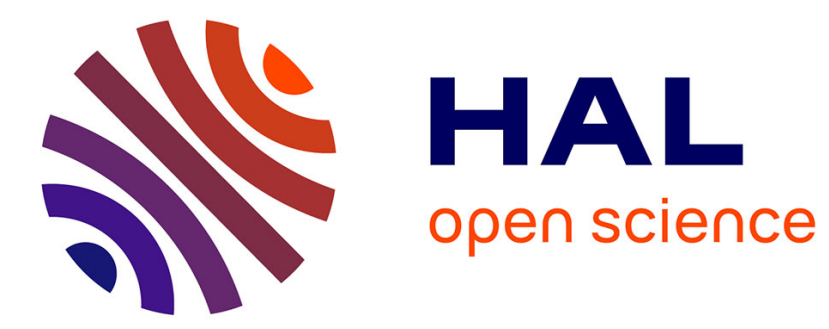

\title{
Crop response to climate change in southern Africa: A comprehensive review
}

Nkulumo Zinyengere, Olivier Crespo, Sepo Hachigonta

\section{To cite this version:}

Nkulumo Zinyengere, Olivier Crespo, Sepo Hachigonta. Crop response to climate change in southern Africa: A comprehensive review. Global and Planetary Change, 2013, 111, pp.118-126. 10.1016/j.gloplacha.2013.08.010 . hal-01062788

\section{HAL Id: hal-01062788 \\ https://hal.science/hal-01062788}

Submitted on 10 Sep 2014

HAL is a multi-disciplinary open access archive for the deposit and dissemination of scientific research documents, whether they are published or not. The documents may come from teaching and research institutions in France or abroad, or from public or private research centers.
L'archive ouverte pluridisciplinaire HAL, est destinée au dépôt et à la diffusion de documents scientifiques de niveau recherche, publiés ou non, émanant des établissements d'enseignement et de recherche français ou étrangers, des laboratoires publics ou privés. 


\title{
Crop response to climate change in Southern Africa: A comprehensive review.
}

\author{
Nkulumo Zinyengere ${ }^{a}$, Olivier Crespo ${ }^{a}$, Sepo Hachigonta ${ }^{b}$ \\ ${ }^{a}$ Climate Systems Analysis Group, Department of Geography and Environmental \\ Science, University of Cape Town, Private Bag X3, Rondebosch 7701, Cape Town, \\ South Africa \\ ${ }^{b}$ Food Agriculture and Natural Resources Policy Analysis Network (FANRPAN), 141 \\ Cresswell Street, Weavind Park 0184, Pretoria, South Africa
}

\begin{abstract}
Concern over future food security in southern Africa has led to various studies that assess the impact of climate change on crops in the region. The results vary according to applied methods and tools. This study reviewed and consolidated results from 19 recent studies which quantitatively project the impact of climate change on crops for the $21^{\text {st }}$ century in southern Africa. Results were assessed according to crop modelling techniques, which included process-based, statistical and economic (Ricardian) modelling. Studies were assessed for their reporting and recommendations concerning adaptation and $\mathrm{CO}_{2}$ fertilisation. Results suggest that the aggregate impact of climate change on crops in southern Africa will be negative. Maize yields are projected to decline on average by $18 \%$. The collective impact of climate change on all crop yields shows a median decline of $-11 \%$ and $-14 \%$ respectively under process-based and statistical methodologies. Median impacts show declining crop yields through the $21^{\text {st }}$ century. No significant change in the near future, $-18 \%$ for the mid century and $-30 \%$ for late century. GCM driven Ricardian projections are highly variable. However, uniform climate scenarios project a median revenue decline. Notwithstanding the challenges of such a review; lack of data, bias towards reported methods and tools, uncertainty, scale etc., results indicate that climate change may impact southern African crops in important ways thereby making adaptation essential. Adaptation and $\mathrm{CO}_{2}$ fertilisation could potentially moderate the negative impacts of climate change. This implies a need for studies into future adaptation that consider $\mathrm{CO}_{2}$ fertilisation.
\end{abstract}

Keywords: Crops, climate change, southern Africa, modelling, adaptation

\footnotetext{
*Corresponding author,

Climate Systems Analysis Group, Department of Geography and Environmental Science, University of Cape Town, Private Bag X3, Rondebosch 7701, Cape Town, South Africa

E-mail:nkulumo@csag.uct.ac.za
}

Fax: +27216505773

Phone: +27 216505774 ; +27842553826 


\section{Introduction}

Southern Africa (SA) is one region that has been shown to be highly vulnerable to climate related risk due to the region's low coping and adaptation capacity (IPCC, 2007). Over $60 \%$ of the region's livelihoods depend on agriculture in one way or the other (Cooper et al., 2008). Agriculture is mostly practiced under rain fed conditions (Twomlow et al., 2008), thereby making crop production in SA particularly prone to climate change and variability (Ziervogel, 2008). This has led to a lot of research on the potential impact of climate change on crop production in SA (Chipanshi et al., 2003; Gbetibouo and Hassan, 2005; Fischer et al., 2005; Abraha and Savage, 2006; Liu et al., 2008; Thornton et al., 2011).

Climate change impact studies make use of simulation models to project how crops will respond to future climate. Considering the inherent complexity of systems being simulated, numerous uncertainties arise during the simulation process. These uncertainties emanate from incomplete data, limited knowledge of systems being modelled, methods and tools. Scientists however make use of available data, tools and methods in the best possible way to attempt to make informed projections. The last decade has a substantial body of work on climate change impacts on crops whose results vary considerably across regions and within SA (Jones and Thornton et al., 2003; Rosenzweig and Iglesias, 2003; Parry et al., 2004; Walker and Schulze, 2006; Jain, 2007; Lobell et al., 2008; Thornton et al., 2009; Nelson et al., 2010; Roudier et al., 2011). These studies suggest that the production of major crops is under threat from climate change and that efforts to adapt food crop production systems to climate change should be explored in order to promote future food security.

Impact studies in SA produce different results based on applied methodologies, tools and location of study within the region. While these studies are useful individually, a collective assessment would allow consistent information to be extracted. It would increase confidence in study results, especially towards adaptation planning. This study attempts to provide a collective insight of climate change impacts on crops in SA by reviewing and analysing recent literature. A review of local, regional and global studies which quantitatively assess the impact of climate change on various food crops in SA is done. Results from these studies are consolidated and presented according to the tools and methods used in order to describe the magnitude and direction of climate change impacts on crops. Tools and methods used in reviewed studies are described thereby placing projected climate change impacts within the context of their strengths and weaknesses. Results are discussed and linked to adaptation strategies suggested in literature. Despite the limitations of this review, this study can help to better understand the range of impacts projected by various studies, point out more or less confident projections and what the implications are for the adaptation of vulnerable crop production systems in SA. 


\section{Background}

\subsection{Global climate trends and projections}

The Intergovernmental Panel on Climate Change (IPCC) fourth assessment report (AR4), states that global temperatures are on the rise. Instrumental records of temperature over the period of 100 years ending 2005 clearly show an average global increase of $0.74{ }^{\circ} \mathrm{C}$ with the $2^{\text {nd }}$ half of the century being twice as warm as the entire period (IPCC, 2007). Continental average temperatures over the same period also rose similarly. Notably, global and continental temperature rise is clearly attributable to human activity. The IPCC (2007) reports an $80 \%$ rise in annual carbon dioxide $\left(\mathrm{CO}_{2}\right)$ emissions since 1970. This and longer term green house gases (GHGs) emission rise is reportedly a result of fossil fuel burning and land use changes among other human activities.

While global temperature projections are consistent over time, rainfall varies temporally, spatially and across models, such that no general trend is apparent on a global scale. However, it has been noted that rainfall variability globally is quite high. There has been an increase in the parts of the world that are continuously being affected by excessive and insufficient rainfall (Porter and Semenov, 2005). Of concern in low income regions like Africa and some parts of Asia is the fact that regionally important food crop producing areas have been experiencing changes in rainfall variability and intensity.

Projecting into the future, most climate models agree on global temperature rise, albeit with varying degrees of warming (IPCC, 2007). As shown in Table 1, mean temperatures are consistently projected to rise by the end of the $21^{\text {st }}$ century. Mean temperature projections range from increases of $1.8{ }^{\circ} \mathrm{C}$ to $4.0^{\circ} \mathrm{C}$, according to the different $\mathrm{CO}_{2}$ emissions scenarios defined in the special report on emission scenarios (SRES). On the other hand, future rainfall projections are not consistent. This poses a challenge when simulating the impact of climate change on crop development and devising adaptation strategies in Africa where a large portion of the population relies on rainfed crop production for food.

\subsection{Future climate projections in Africa}

A general warming larger than the global mean warming is predicted for all seasons across Africa. These projections are summarised in Table 2. All 21 General Circulation Models (GCMs) in the IPCC AR4 agree on warming across Africa. However, the degree of warming projected varies from one region to the other within the continent. Higher mean temperatures are projected for the Sahel compared to other regions. Projected temperature changes also vary from one season to the other within regions. Projections of future rainfall are more uncertain. Climate models do not agree on the magnitude or direction of rainfall changes. Mean annual rainfall is projected to increase in West Africa (+2\%) and East Africa (+7\%). Mean annual rainfall is projected to decrease in Sahel $(-6 \%)$ and SA (-4\%). Marked variations are 
projected within seasons. These variations are significant for future crop production and food security.

In SA, projected climates have potentially negative implications for crop production and livelihoods. Major crop production systems which support most of the livelihoods in SA are located in the dry sub-humid and semi-arid zones. These regions are already experiencing high temperatures with a significant portion experiencing below 1000 mm of annual rainfall (Nhemachena, 2009). Projections of temperature increase or rainfall decline could translate into widespread crop failure. Table 2 shows that SA is expected to have notably high temperature increase $\left(3.7^{\circ} \mathrm{C}\right)$ in the early summer season months of September, October and November (SON) compared to other regions. This is particularly significant for crop production as it coincides with the beginning of summer cropping in most parts of the region. While climate models disagree on whether the changes in rainfall in SA will be positive or negative, rainfall is consistently projected to decline especially in the winter months of June, July and August (JJA) and the $1^{\text {st }}$ half of the summer cropping season (SON). Early summer (SON) rainfall is projected to decline on average by $13 \%$. This is potentially unfavourable for crop production in SA especially given the projected high rise in mean early summer temperatures. However, climate projections also suggest that increases in late summer rainfall (total and number of rain days) can be expected over SA (Tadross et al., 2009). Therefore, climate change may not only be damaging to crop production but may present opportunities that can be exploited through adaptation. However, it is important to note that climate projections are made in the context of still developing regional modelling science, which is still not fully understood. They are therefore uncertain.

\section{Methods used to project crop response to climate change in SA}

In assessing the impact of climate change on crops, climate scenarios are used to drive crop models. This section discusses the two crop modelling techniques which have been commonly employed to perform climate change impact assessments for crop production in SA. These methods include process-based and empirical crop modelling (statistical and Ricardian economic approach). Strengths and weaknesses of each method are also discussed.

\subsection{Process-based crop modelling}

The predominant tool for assessing the impacts of climate change on agricultural productivity is the process-based crop growth simulation model (Hertel and Rosch, 2010). Process-based crop models were developed to simulate crop responses to environmental conditions at the plot and field level. They do this by computing crop dynamics based on deterministic (cause and effect) equations and simulation of underlying processes at time scales of minutes to days (Tubiello and Ewert, 2002). Many impact studies on SA have employed process-based models to project the 
impacts of climate change on crops at regional (tens to a couple of hundred kilometres) (Chipanshi et al., 2003; Jones and Thornton, 2003; Liu et al., 2008; Fischer et al., 2005; Thornton et al., 2011). This is despite the fact that crop models were made for finer spatial scales where parameter demands can be fulfilled better with fairly homogeneous data as done by (Abraha and Savage, 2006; Schulze and Walker, 2006). This is one of the immediate challenges of using process-based models for projecting crop response to climate change. They do not directly provide information on climate impacts at larger scale (Roudier et al., 2011). Yet climate models typically operate at large scale. Climate data therefore needs to be downscaled to the scale of a crop model or a crop model matched to the scale of climate model output (Challinor et al., 2007). The spatial mismatch introduces additional uncertainty in crop response projections. Process-based models are also limited by the bio-physical processes they are based on. Some models are based on the concept of radiation-use efficiency (RUE), whilst others are based on water-use or nitrogen-use efficiency, which are all determined by the aims for which the models are developed (Challinor et al., 2009).

The Decision Support System for Agro-technology Transfer (DSSAT) is the most widely applied process-based model in reviewed studies. DSSAT was applied by (Chipanshi et al., 2003; Thornton et al., 2011). It integrates single crop models into a modular framework. Among others it includes CERES-maize (Jones and Thornton, 2003; Walker and Schulze, 2006), SOYGRO for soybean (Parry et al., 2004), and CANEGRO for sugarcane (Knox et al., 2010), which were individually used in reviewed studies. Apart from DSSAT, Liu et al. (2008) use the Erosion Productivity Impact Calculator (EPIC) in combination with a Geographic Information System (GIS) called GEPIC while Fischer et al. (2005) incorporate GIS into their model called Agro-Ecological Zone (AEZ) model to make impact assessments. Abraha and Savage (2006) use the cropping system simulation model (CropSyst). All process-based models are invariably short of the complexities of the real world crop production systems (White et al., 2011). Despite these challenges, process-based models allow us to carry out near-life experiments to infer current and future responses of crops to climate and the environment thereby allowing us to plan ahead. This is one of the reasons this method is popular with climate change impact analysts.

\subsection{Empirical crop modelling}

\subsubsection{Statistical}

Statistical models use historical data on crop yields and climate to develop statistical relationships (Lobell and Burke, 2010). They were intrinsically designed to operate at the multi-seasonal, regional scale, and are thus best suited for analyzing inter-annual variability of regional production (Hertel and Rosch, 2010). This makes them an attractive alternative to process-based methods when assessing climate change impacts at a coarse spatial scale. Recent impact studies performed in SA using statistical methods include Lobell et al. (2008); Burke et al. (2009); Schlenkler and Lobell (2010). The main advantages of statistical models are their limited reliance on 
field calibration data, and their transparent assessment of model uncertainties through the use of coefficients of determination and confidence intervals (Hertel and Rosch, 2010). However, statistical models are not based on cause and effect and so rely on predicting future responses based on past relationships (White et al., 2011). These past relationships may not hold in the future. Furthermore, past relationships are hard to validate in regions like SA where extensive historical data may not exist. Another limitation of statistical models for future crop response projection is the absence of adaptation responses. Changes in varieties grown, planting and harvesting dates, etc., are not taken into account (Lobell and Burke, 2010). This limitation of statistical models is usually overcome by introducing economic models which allow for analyses of adaptation in the context of farm-level revenues. One of these directly translates crop response to climate into economic outcomes and has been extensively applied in SA in the recent past. We describe it hereafter.

\subsubsection{Ricardian}

The Ricardian approach (Mendelson et al., 1994) focuses on the economic impact of climate change on agriculture. The method considers that farmers are economically prudent and therefore select farming activities which give the highest return on any given piece of land. The method relates climate variation or change with fluctuations in land value. The Ricardian approach has been adapted for impact studies in or including SA by Gbetibouo and Hassan (2005); Kurukulasuriya and Mendelson (2006); Mano and Nhemachena (2006); Benhin (2008); Jain (2007); Seo and Mendelson (2008); Kurukulasuriya and Mendelson (2008); Nhemachena (2009). In SA, net revenues are used instead of land values because of the poorly developed land markets. The major advantage of this empirical approach is that it not only includes the direct effect of climate on productivity but also the adaptation response by farmers to local climate by accounting for the cost of different adaptation pathways (Kurukulasuriya and Mendelson, 2007). Like all empirical approaches, the Ricardian approach is limited by the use of current or past relationships which may not exist in the future. These relationships are also constrained by a lack of historical data in SA. The method also assumes that prices are constant. This is an oversimplification as prices fluctuate significantly depending on global markets. This leads to the over estimation of gains and underestimation of loses. However, the fact that the Ricardian approach offers the simplicity of empirical methods and the opportunity to analyse the effect of adaptation options makes it an attractive method. In this review, Ricardian studies are analysed separately from the other methods because they consider monetary impacts not yield. Furthermore, they are given in summary since they mostly come from similar studies under a World Bank/Global Environmental Facility commissioned study in Africa (Kurukulasuriya et al., 2006). 


\section{Results}

The paper reviews studies on climate change impacts on crop production in SA. The studies reviewed were done in the decade 2001-2011. Impact studies were reviewed through an analysis of major on-line databases. The review was limited to studies that clearly quantified changes in crop production or revenues between a present/past and future period either numerically or graphically. In total, 19 studies are reviewed and presented. The economic results emerging from the Ricardian approach come from studies made for particular countries in SA (Zambia, Zimbabwe and South Africa) and others including countries in SA and sub-Saharan Africa (SSA), thereby resulting in potential overlaps. Table 3 shows reviewed studies according to climate scenarios, crop modelling methods, area coverage, crop type and projected time period within the $21^{\text {st }}$ century (Early (2020-2039), Mid (2040-2069) and Late (2070-2100)). It also shows whether a study included carbon dioxide $\left(\mathrm{CO}_{2}\right)$ effects, or adaptation.

\subsection{Compiled independent projections}

Jones and Thornton (2003) projected that maize yields will likely decline in most countries in SA by an average of $10 \%$ by mid $21^{\text {st }}$ century under rainfed small scale production. Their study was performed across two continents, sub Sahara Africa (SSA) and Latin America. Thornton et al. (2011) concluded that given $5{ }^{\circ} \mathrm{C}$ of future warming, maize and bean production in SA could decline by $16 \%$ and $68 \%$ respectively by late $21^{\text {st }}$ century. Liu et al. (2008) estimated that, climate change will lead to $18 \%$ lower yield for wheat, $7-27 \%$ higher yield for millet, up to $7 \%$ higher yield for rice, $4 \%$ higher yield for maize, and negligible change in sorghum and cassava in the early $21^{\text {st }}$ century. For all crops as a whole, they estimated a slight increase in crop yields of 1.6-3.3\%. A global study by Parry et al. (2004) concluded that total crop yield in Africa may decrease up to $30 \%$ in the late century. They made this assessment for wheat, maize, rice, and soybean. Cereal yields for SA showed up to $5 \%$ decline for all scenarios without $\mathrm{CO}_{2}$ fertilisation for the early century, 5-30\% decline in mid century and a consistent $10-30 \%$ decline for late century. In a study for SSA, Fischer et al. (2005) showed a potential 5-50\% declined in cereal yields for most parts of SA by late century. Chipanshi et al. (2003) examined the response of maize and sorghum in Botswana to uniform future climate scenarios. The country was split into two regions, the sand veldt and hard veldt. Simulated yields declined by $36 \%$ for maize and $31 \%$ for sorghum in the sand veldt region and $10 \%$ for both maize and sorghum in the hard veldt.

Some studies have been done at finer spatial scales, thereby allowing for the assessment of potential adaptation strategies. Knox et al. (2010) assessed the impact of climate change on sugar cane in Mhlume, a district in Swaziland. They projected a decline in sugarcane yields of up to $13 \%$ by mid century. They also showed that with appropriate irrigation, sugarcane yields would increase over the same period. Walker and Schulze (2006) examined the response of smallholder maize production in Potshini village, Kwazulu Natal, South Africa to late $21^{\text {st }}$ century climates. They 
projected a decline in average maize yields of $30 \%$ but also demonstrated that varying fertiliser and manure applications is a viable management strategy to adapt to climate change. The positive effect of adjusting management strategies was also confirmed by Abraha and Savage (2006) in a site study (Cedara, Kwazulu Natal, South Africa) on the effect of shifting planting date on maize yields in a changing climate. Projected maize yields increased from baseline yields by $10-12 \%$. They concluded that shifting planting dates could be a useful adaptation to climate change. However, reviewed literature shows that these kinds of adaptation studies are limited in SA.

In a global study which projected crop response to climate in the early $21^{\text {st }}$ century using statistical methods, Lobell et al. (2008) showed that without sufficient adaptation measures, SA will likely suffer negative impacts on crops (Fig. 1). The study projected an average decline in maize, wheat, soybean, sugar cane, and sorghum yields of $28 \%, 16 \%, 8 \%, 6 \%$, and $2 \%$ respectively. Cassava was unchanged while rice yield was projected to increase by $5 \%$ and ground nuts by $2 \%$. Schlenkler and Lobell (2010) used panel statistical models to investigate crop response to climate change in SSA in the mid $21^{\text {st }}$ century. They projected negative impacts of warming for all models used and crops investigated. The median impacts showed a 22\%, 17\%, 17\%, $18 \%$, and $8 \%$ decline in yields for maize, sorghum, millet, groundnut, and cassava, respectively. Severe cases showed a decline of $27-32 \%$ for all crops except cassava. Burke et al. (2009) also used statistical methods to show, without quantifying yield changes, that maize, sorghum and millet in SA will by mid century experience climates which are significantly different from those of the present. They concluded that this warrants investment in adaptation measures.

\subsection{Overall projected impacts by process-based and statistical methods}

A comparison of projected crop response to future climate for SA using process-based and statistical-based methods is summarised in Fig. 2. Although the two methods are different in nature, they all predict a median decline in SA crop yields (process-based: $-11 \%$; Statistical-based: $-19 \%$ ) under climate change for all projected future time periods combined. The process-based method however has a much larger range of crop yield changes (-68\% to $27 \%$ ) than the statistical method. The combined crop yield response projections for the process-based and statistical methods separated by time periods in the $21^{\text {st }}$ century are summarised in Fig. 3. A decline in crop yields is projected to increase with time. Projected median changes are $0 \%$ for early $21^{\text {th }}$ century, $-18 \%$ for mid $21^{\text {th }}$ century and $-30 \%$ for late $21^{\text {th }}$ century. The range of projections for the early $21^{\text {st }}$ century shows almost equal projections of yield increase as yield decline. However, projected percentage crop yield changes for mid and late $21^{\text {st }}$ century consistently show decline.

\subsection{Ricardian Approach}

The Ricardian approach is commonly used for studying the impact of climate change on crop production in SA. These results are assessed separately from the other methods because of the different units of measurement i.e. monetary as opposed to the 
production (yields/ha) applied by the other approaches. Some Ricardian studies reviewed used uniform future climate scenarios by varying temperature and rainfall by constant amounts e.g. $+1{ }^{\circ} \mathrm{C}$ or $+10 \%$ increase in rainfall (Gbetibouo and Hassan, 2005; Mano and Nhemachena, 2006; Jain, 2007). The general trend for projections made using uniform climate scenarios is a decline in farm net revenues across all farm types and dry land farms in SA. Fig. 4 shows median decline in farm net revenues of $12 \%$ for dry land farms and $14 \%$ for all farm types. The range of projections for dry land farms is negative while that of all farms combined ranges from negative to positive change in revenue.

The percentage of farm revenue from the Ricardian approach based on GCMs scenarios was ordinarily more variable compared to the uniform scenarios of temperature and rainfall. This led to extreme revenue changes as shown in Fig 4. In some reviewed studies, farm revenue was found to decline by up to $100 \%$ for all farm types and up to $75 \%$ for dry land farms. At the same time, farm revenue also increased by up to $82 \%$ for all farms. Fig. 4 also shows that while the dispersion of projected revenue change increases with the effect of GCM scenarios, the median change in farm net revenue is negative for all climate projections and farm types.

\subsection{Adaptation to climate change in SA}

Adaptation is an important component of climate change impact studies. A number of reviewed studies suggest that adaptation of crop production systems in SA is essential under climate change. However, the levels at which adaptation has been considered varies (Table 3). Some studies do not consider adaptation. Others consider it partially e.g. through general assumptions over a large study area or in full e.g. through assumed complete adaptation (Ricardian). However, all studies include adaptation options as part of their discussions, conclusions or recommendations. This section presents the different levels of engagement with adaptation by the impact studies along with their suggestions for adapting to modelled future impacts of climate on crops in SA.

Studies that don't consider adaptation however suggest a number of potentially useful adaptation options by extrapolating from the impact study. Chipanshi et al., 2003 and Jones and Thornton (2003) did not include adaptation in their impact assessments but suggested that changing of farm management strategies and engagement in off-farm income generation were potential future adaptation options in SA. Thornton et al., 2011 suggested the development and use of suitable crop varieties. Despite statistical methods inherently excluding adaptation in their projections, Lobell et al., 2008 and Schlenkler and Lobell (2010) agree that the development of irrigation technologies and new and improved crop varieties will be a useful way of adapting crops to future climates.

Other researchers consider adaptation in their impact studies. Fischer et al., 2005 considered farm-level adaptation (changing crop calendar and changing cropping 
systems) and regional and global markets adjustments. They concluded that adaptation could reduce negative impacts of climate change on crop production. Parry et al. (2004) performed an impact study by considering current irrigation and farmlevel adaptation. They concluded that current adaptation practices may not be able to reduce the negative effect of future climate on crops. Liu et al. (2008) considered changing cropping dates as an adaptation and concluded that investment in research towards improved crop varieties as well as adjusting management strategies (crop varieties, water and fertiliser management) were potentially useful for adapting to future climates. All crop projections made using the Ricardian approach considered adaptation. Recurrent suggestions for suitable adaptation options to future changes in climate include irrigation, breeding and use of appropriate crop varieties, farmer access to extension services and markets as well as off-farm income generation.

The above mentioned studies performed impact assessments at a coarse spatial scale (national to regional). A few studies projected crop responses to future climates at finer spatial scales (district and site). This allowed them to assess adaptation more explicitly with a focus on local relevance and application. Walker and Schulze (2006) assessed the impact of climate change on maize with various treatments of tillage practices and fertiliser applications at village level in Kwazulu Natal, South Africa. They recommended conservation tillage and the application of optimal fertiliser levels as potential adaptation options for smallholder farming communities. They also suggested rainwater harvesting and supplementing incomes through off-farm employment. Abraha and Savage (2006) assessed the effect of various planting dates. They acknowledged the usefulness of adjusting planting dates for adapting to climate change at the local level. Knox et al., 2010 considered irrigation in their assessment of the impact of climate change on sugarcane yields in Mhlume district, Swaziland. They concluded that current irrigation levels will need to increase by $20-22 \%$ in order to maintain current optimal production levels.

\section{5 $\mathrm{CO}_{2}$ fertilisation effects}

Rising $\mathrm{CO}_{2}$ levels have been found to be the driving force behind global warming and climate change. However, depending on crop physiology (C3 or $\mathrm{C} 4$ pathways) increasing $\mathrm{CO}_{2}$ levels in the atmosphere can also increase crop yields through $\mathrm{CO}_{2}$ fertilisation (IPCC, 2007). Knox et al. (2010) noted that $\mathrm{CO}_{2}$ fertilisation offset the impacts of climate change and led to higher yields in Swaziland. Projected sugarcane yields increased by $15 \%$ with doubling $\mathrm{CO}_{2}$ by 2050 . Walker and Schulze (2006) found that a doubling $\mathrm{CO}_{2}$ increased maize yields in Potshini, South Africa. They concluded that with a doubling in $\mathrm{CO}_{2}$ levels, the potential positive and negative drivers of maize yield changes would be self cancelling, leading to maize yield increase thereafter. Abraha and Savage (2006) noted that given non-limiting conditions of water, the effect of $\mathrm{CO}_{2}$ was such that maize yields increased with doubling $\mathrm{CO}_{2}$ and $2{ }^{\circ} \mathrm{C}$ temperature rise. However when temperature rises by $4{ }^{\circ} \mathrm{C}$, the positive effect of $\mathrm{CO}_{2}$ fertilisation is offset. Liu et al., 2008 partly attribute the projected overall increase in crop yields (1.6-3.3\%) to $\mathrm{CO}_{2}$ fertilisation in the early 
$21^{\text {st }}$ century. Contrary to other studies, Parry et al. (2004) concluded that the effect of rising $\mathrm{CO}_{2}$ in the region is unable to counteract the projected cereal yield decline. Maize yields still fall by $30 \%$ despite the rising $\mathrm{CO}_{2}$ levels under the A1FI climate scenario. Chipanshi et al., 2003 concluded that the positive effects of rising $\mathrm{CO}_{2}$ are unlikely to be realised on maize and sorghum in Botswana. Statistical crop response projections made by Lobell et al., 2008 and Schlenkler and Lobell (2010) do not consider the effect of $\mathrm{CO}_{2}$. Economic impact projections based on the Ricardian approach also exclude the effect of $\mathrm{CO}_{2}$.

\section{Discussion}

\section{Projected impacts of climate change on crops: Implications for adaptation}

Most studies reviewed assess the impact of climate change on maize, which is the staple food crop in the region. With the exception of Abraha and Savage (2006) and Liu et al., 2008, projections of maize yield response to climate change show a decline. A decline of maize production would significantly stress food security in the region. The overall effect of climate change on the yield of all crops put together based on projections by the process-based and statistical methods is also negative. This strengthens the suggestion of stress on food security due to climate change and limits adaptation options such as crop shifts. However, there is high variation in yield projections based on the process-based methods compared to the statistical methods (Fig. 2). This is partly due to process-based methods simulating the physiological response of crops to various environmental factors and thus capturing a wide range of possible non-linear crop responses, while the statistical methods are limited by established historical relationships between crop yields and climate. Furthermore, some projections by process-based methods take $\mathrm{CO}_{2}$ and adaptation into account, thereby allowing for potential benefits of $\mathrm{CO}_{2}$ fertilisation and adaptation strategies while statistical methods inherently exclude them.

Projections of crop response by time period (Fig. 3) show no change in median crop yields in the early $21^{\text {th }}$ century for all crops combined. The range of projections for the early $21^{\text {st }}$ century shows uncertainty about the direction of crop response, there is almost an equal projection of increase in yields as decrease. The uncertainty is common in both process-based and statistical methods in the early century e.g. Lobell et al., 2008 and Liu et al., 2008 as shown in Fig 1. This is partly due to the moderate climate change projections for the early part of the century where only an increase of $1-2{ }^{\circ} \mathrm{C}$ is projected for temperature in the region (IPCC, 2007). The positive effects of $\mathrm{CO}_{2}$ and adaptation strategies could still offset the potential negative effects of future climate as shown by positive yields projected by Liu et al. (2008). The positive effect of $\mathrm{CO}_{2}$ and adaptation was also confirmed through increased maize yields by Abraha and Savage (2006). However, it is important to note that crop models overestimate the effect of $\mathrm{CO}_{2}$ on plant growth and yield (Challinor et al., 2009). Parry et al. (2004) also suggests that the effect of $\mathrm{CO}_{2}$ and presently practiced adaptation strategies 
(irrigation and farm management practices) may have no noticeable effect on early century crop yields. Hence care needs to be taken when crediting $\mathrm{CO}_{2}$ fertilisation for positive crop yields. Further into the century (mid and late), the effect of climate becomes more severe as temperature increases and rainfall becomes more variable such that crop responses projected by both methods during these periods are negative (Fig. 3). The fertilisation effect of $\mathrm{CO}_{2}$ at this time may be unable to compensate higher temperatures and unsuitable rainfall. Due to the associated climate physical processes and predictors, temperature projections are more robust than rainfall projections. Therefore whatever the rainfall change, high temperatures in the mid to late century can negatively affect crop yields through water stress from high evapotranspiration and by reducing crop growth periods. Changes in rainfall variability in the mid to late century can lead to changes in rainfall distribution, more frequent and intense extremes (e.g. dry-spell duration, rainstorms). Even where rainfall change projections are insignificant, these perturbations of climate could be highly detrimental to crop production.

Projected crop response to uniform climate scenarios under Ricardian studies show $12-14 \%$ decline in net revenues (Fig. 4). The variation in projected revenues is much less than that projected using GCM scenarios especially for all farm types. This is partly because uniform scenarios applied by some studies were moderate e.g. $+1{ }^{\circ} \mathrm{C}$ and $+7 \%,-10 \%,+1 \mathrm{~mm}$ rainfall and therefore do not capture a wide range of possible climatic variations as done by GCMs. Dry land farms are shown to have less increase in revenue under GCM driven scenarios compared to all farm types combined probably because of the lack of irrigation. Dry land farms in SA are also commonly known to have poor soils from years of nutrient mining (Twomlow et al., 2008), this can contribute to reduced economic benefits even with expectations of favourable future climate. The effect of different GCM projections and the sensitivity of the Ricardian approach to rainfall make revenue changes to future climate highly variable. This makes it hard to make firm conclusions about crop responses to climate change in SA using this method. However, median revenue projections are negative, regardless of the climate scenarios used. This suggests that despite the broad range of projections, crop production systems in SA may suffer future economic losses as a result of climate change.

All studies reviewed suggest that adaptation of crop production systems to climate change in SA is essential. Various adaptation options have been identified across the different studies and methodologies as potentially useful under a changing climate. The development and appropriate use of climate adapted crop varieties is a frequently suggested adaptation option. Variety selection for drought resistance and heat tolerance is likely to reduce the negative impacts of a warmer future climate with variable rainfall. Jones and Thornton (2003) suggest that given the history of cereal yield increases owing to crop breeding and technological development, moderate yield losses such as a $10 \%$ decline in maize yields could be compensated through the use of climate adapted varieties. Many studies also recommend the diversification of 
household income through off-farm employment. Such a strategy could be useful to over $60 \%$ of smallholder farmers in SA who rely on rainfed crop production and natural resources for food and livelihoods (Ziervorgel, 2008; Cooper et al., 2008). Reducing the reliance of livelihoods on rainfed crop production could cushion smallholder communities from unfavourable future climate and crop losses. Increased access to markets as suggested by several studies may help to improve on-farm profitability. Farmers would be able to save and to intensify farming, thereby increasing their capacity to cope with unfavourable impacts of climate change while also readily exploiting opportunities that may arise.

Most studies emphasise on-farm adaptation options, mainly through the adjustment of farm management strategies (planting dates, changing crop types, appropriate water and fertiliser management and irrigation). Since smallholder farmers in SA have been known to historically cope with variations in climate through adjusting management strategies (Twomlow et al., 2008), such an option could be a natural choice for smallholder farming communities to adapt to future climate. Suggested improvements in climate forecasting and dissemination of forecasts, complemented by enhanced access to extension services would better prepare farmers to make use of these management strategies especially given increased future rainfall variability. Farmers would be better able to use irrigation and in-field water harvesting timely and appropriately thereby reducing the negative impact of dry spells and exploiting the potential benefits of increased rainstorms. Farmers would also be able to time planting and fertiliser application well, in so doing avoid crop losses resulting from insufficient moisture for germination at the beginning of the season and the leaching of nutrients. All suggested adaptation options will most likely include various stakeholders like governments, private organisations, non-profit organisations and farmers themselves. Climate change adaptation strategies should therefore be developed and recommended within the context of stakeholders and their different roles.

\section{Conclusions}

This study reviewed and consolidated 19 climate change impact studies on crop production in SA over a decade (2001-2011). The review combined results from studies across several methods and tools of projecting crop response to future climate. These results suggest that aggregate impacts of climate change on crops in SA will be negative. Maize yields are on average projected to decline by $18 \%$ in the $21^{\text {st }}$ century. This has unfavourable implications for food security in SA where maize yields are a common determinant of food security especially in smallholder farming communities. The collective impact of climate change on all crops reviewed shows a decline of $-11 \%$ and $-14 \%$ respectively based on process-based and statistical methodologies. Median impacts show a declining crop response through the $21^{\text {st }}$ century. No significant change in near future (2020-2039), -18\% for the mid-century (2040-2069) and -30\% for late century (2070-2100). Future crop yield projections are variable. This can be 
attributed to the large dispersion in future climate projections as a result of $\mathrm{CO}_{2}$ emission pathways, climate model structure and data limitations for calibration and validation of climate and crop models. Hachigonta (2011) suggests that climate scenarios from GCMs are the major source of uncertainty in the region. That effect is even more notable for revenue change projections made under Ricardian studies. Revenue changes projected by GCM driven scenarios ranged from a decline of -100\% to an increase of $+82 \%$ of revenues. However, overall projections under Ricardian studies showed a median decline in net revenues. Uniform scenario driven projections showed median revenue decline of $12 \%$ and $14 \%$ in dry land farms and all farm types respectively.

This review helps determine the range of impacts that climate change will have on various crops in SA, especially food crops. This is a first step to developing suitable adaptation measures to reduce such impacts and promote future food security. Reviewing studies that are based on varying assumptions, tools and methodologies is difficult. The study conclusions must be put in the light of lack of quantitative data and bias towards reported methodologies and tools. However, it is clear that climate change will significantly affect crop production in SA. There is a compelling need for adaptation especially for vulnerable smallholder farmers. Research into locally appropriate adaptation options is essential. Smallholder farmers' past and current copping capacity (Twomlow et al., 2008) suggests research could build on this knowledge. Though uncertainty is and will remain significant, prediction tools are useful for the exploration and evaluation of local adaptation alternatives. Such research could be approached through the use of downscaled climate projections. Multiple GCMs and $\mathrm{CO}_{2}$ emissions scenarios can be used to sample climate uncertainty. Furthermore, judicious calibration and validation of crop models for use at the local scale is also important (Challinor et al., 2009). However, setting up crop models satisfactorily at local levels may be challenging in SA where historical data is usually insufficient. Higher $\mathrm{CO}_{2}$ levels could increase crop productivity and should be considered in adaptation studies. Adapting crops to climate change in SA will have to be accompanied by broad investments, the integration of new and appropriate technologies with local knowledge and a coordinated engagement of public and private stakeholders.

\section{Acknowledgements}

We acknowledge the support of the International Development Research Centre (IDRC) through the Food, Agriculture and Natural Resources Policy Analysis Network (FANRPAN) under the project titled "From Research to Policy: Strengthening Institutional Capacity for Linking Climate Change Adaptation to Sustainable Agriculture in Southern Africa." We also acknowledge support from the African Climate Change Fellowship Programme (ACCFP). 


\section{References}

Abraha M.G., Savage M.J., 2006. Potential impacts of climate change on the grain yield of maize for the midlands of KwaZulu-Natal, South Africa. Agriculture Ecosystems Environment. 115: 150-160.

Benhin J.K.A., 2008. South African crop farming and climate change: An economic assessment of impacts. Global Environmental Change 18: 666-678.

Boer G., Flato G., and Ramsden D., 2000. "A Transient Climate Change Simulation with Greenhouse Gas and Aerosol Forcing: Projected Climate for the $21^{\text {st }}$ Century." Climate Dynamics 16: 427-450.

Burke M.B., Lobell D.B., Guarino L., 2009. Shifts in African crop climates by 2050, and the implications for crop improvement and genetic resources conservation. Global Environmental Change 19: 317-325.

Challinor A., Wheeler T., Garforth C., Craufurd P., Kassam A., 2007. Assessing the vulnerability of food crop systems in Africa to climate change. Climatic Change 83: 381-399.

Challinor A. J., Ewert F., Arnold S., Simelton E., Fraser E., 2009. Crops and climate change: progress, trends, and challenges in simulating impacts and informing adaptation. J. Exp. Bot. 60: 2775-2789.

Chipanshi A.C., Chanda R., Totolo O., 2003. Vulnerability assessment of the maize and sorghum crops to climate change in Botswana. Climatic Change 61: 339-360.

Cooper P.J.M., Dimes J., Rao K.P.C., Shapiro B., Shiferaw B., Twomlow S., 2008. Coping better with current climatic variability in the rain-fed farming systems of subSaharan Africa: An essential first step in adapting to future climate change. Agriculture, Ecosystems and Environment 126: 24-35.

Emori S. T. N., Abe-Ouchi A., Namaguti A., Kimoto M., 1999. "Coupled OceanAtmospheric Model Experiments of Future Climate Change with an Explicit Representation of Sulfate Aerosol Scattering." J. Meteorological Society Japan 77: 1299-1307.

Fischer G., van Velthuizen H., Shah M. \& Nachtergaele F. O.. 2002. Global agroecological assessment for agriculture in the 21st century: methodology and results. IIASA RR-02-02. Laxenburg, Austria: IIASA.

Fischer G., Shah M., Tubiello F.N., van Velhuizen H., 2005. Socio-economic and climate change impacts on agriculture: An integrated assessment, 1990 -2080. Phil. Trans. R. Soc. B. 360: 2067-2083 
Gbetibouo G.A., Hassan R.M., 2005. Measuring the economic impact of climate change on major South African field crops: A Ricardian approach. Global and Planetary Change 47: 143-152.

Gordon H. B., Rotstayn L. D., McGregor J. L., Dix M. R., Kowalczyk E. A., O'Farrell S. P., Waterman L. J., Hirst A. C., Wilson S. G., Collier M. A., Watterson I. G., Elliott T. I., 2002. The CSIRO Mk3 Climate System Model. CSIRO Atmospheric Research Technical Paper No. 60. (Available on-line at http://www.cmar.csiro.au/eprint/open/gordon_2002a.pdf )

Hachigonta S., 2011. Assessing maize water requirements in the context of climate change uncertainties over southern Africa. Unpublished $\mathrm{PhD}$ thesis. University of Cape Town. South Africa.

Hertel T.W., Rosch S.D., 2010. Climate Change, Agriculture, and Poverty. Applied Economic Perspectives and Policy. 32(3): 355-385.

IPCC (2007). Climate Change 2007. Synthesis Report. Contribution of Working Groups I, II and III to the Fourth Assessment Report of the Intergovernmental Panel on Climate Change. IPCC, Geneva, Switzerland.

Jain S., 2007. An empirical economic assessment of impacts of climate change on agriculture in Zambia. CEEPA Discussion Paper No. 27. Centre for Environmental Economics and Policy in Africa. Pretoria, South Africa: University of Pretoria.

Jones PG, Thornton PK., 2003. The potential impacts of climate change on maize production in Africa and Latin America in 2055. Global Environment Change 13(1): 51-59.

Jones J.W., Hoogenboom G., Porter C.H., Boote K.J., Batchelor W.D., Hunt L.A., Wilkens P.W., Singh U., Gijsman A.J., Ritchie J.T., 2003. The DSSAT cropping system model. Europ. J. Agronomy. 18: 235-265.

Johns T.C., Carnell R.E., Crossley J.F., Gregory J.M., Mitchell J.F., Senior A.C., Tett S.F.B., Wood R.A., 1997. The second Hadley Centre coupled ocean-atmosphere GCM: model description, spinup and validation. Climate Dynamics 13: 103-134.

Johns T.C., Gregory J.M., Ingram W.J., Johnson C.E., Jones A., Lowe J.A., Mitchell J.F.B., Roberts D.L., Sexton D.M.H., Stevenson D.S., Tett S.F.., Woodage M.J., 2003. Anthropogenic climate change for 1860-2100 simulated with the HadCM3model under up-dated emissions scenarios. Climate Dynamics 20: 583-612.

Knox J.W., Rodriguez Diaz J.A., Nixon D.J., Mkhwananzi M., 2010. A preliminary assessment of climate change impacts on sugarcane in Swaziland. Agricultural Systems 103: 63-72. 
Kurukulasuriya P., Mendelsohn R., 2006. A Ricardian analysis of the impact of climate change on African cropland. CEEPA Discussion Paper No. 8. Special Series on Climate Change and Agriculture in Africa. ISBN 1-920160-01-09.

Kurukulasuriya P., Mendelsohn R., Hassan R., Benhin J., Deressa T., Diop M., Eid H.M., Fosu K.Y., Gbetibouo G., Jain S., Maddison D., Mahamadou A., Mano R., Mariara J., El-Marsafawy S., Molua E., Ouda S., Ouedraogo M., Sene I., Niggol S., Dinar A., 2006. Will African agriculture survive climate change? World Bank Economic Review 20 (3), 367-388.

Kurukulasuriya, P \& Mendelsohn, R, 2007. Modeling endogenous irrigation: The impact of climate change on farmers in Africa. World Bank Policy Research Working Paper 4278. World Bank, Washington, DC.

Kurukulasuriya P., Mendelson R., 2008. Crop switching as a strategy for adapting to climate change. AfJARE 2: 1.

Liu J., Williams J.R., Zehnder A.J.B., Yang H., 2007. GEPIC-modelling wheat yield and crop water productivity with high resolution on a global scale. Agricultural. Systems. 94 (2): 478-493.

Liu J., Fritz S., van Wesenbeeck C.F.A., Fuchs M.,You L., Obersteiner M., Yang H., 2008. A spatially explicit assessment of current and future hotspots of hunger in SubSaharan Africa in the context of global change. Global and Planetary Change 64: 222235 .

Lobell D.B., Burke M.B., Tebaldi C., Mastrandrea M.D., Falcon W.P., Naylor R.L., 2008. Prioritizing climate change adaptation needs for food security in 2030. Science 319: 607.

Lobell D.B., Burke M.B., 2010. On the use of statistical models to predict crop yield responses to climate change. Agricultural and Forest Meteorology, 150 (11): 14431452.

Mano R., Nhemachena C., 2006. Assessment of the economic impacts of climate change on agriculture in Zimbabwe: a Ricardian approach. CEEPA Discussion Paper No. 11. Centre for Environmental Economics and Policy in Africa. Pretoria, South Africa: University of Pretoria.

McGregor J. L., Dix M.R., 2001. The CSIRO Conformal Atmospheric-cubic GCM. IUTUM Symposium on advances in mathematical modelling of atmosphere and ocean dynamics. Hodnett P. F ed. Kluwer 197-202.

Mendelson, R., Nardhaus W., Shaw D., 1994. The Impact of Global Warming on Agriculture: A Ricardian Analysis. American Economic Review 84(88): 753-771.

Nelson G.C., Rosegrant M., Palazzo A., Gray I., Ingersoll C., Robertson R., Tokgoz S., Zhu T., Sulser T.B., Ringler C., Msangi S., You L., 2010. Food Security, Farming, 
and Climate Change to 2050: Scenarios, Results, Policy Options. International Food Policy Research Institute, Washington, DC.

Nhemachena C., 2009. Agriculture and future climate dynamics in Africa: Impacts and adaptation options. Unpublished $\mathrm{PhD}$ in Environmental economics thesis. University of Pretoria.

Parry M.L., Rosenzweig C., Iglesias A., Livermore M.G.F., 2004. Effects of climate change on global food production under SRES emissions and socio-economic scenarios. Global Environmental Change 14: 53-67.

Porter J.R., Semenov M.A., 2005. Crop responses to climatic variation. Phil. Trans. R. Soc. B 360: 2021-2035.

Ritchie, J.T., Otter, S., 1984. Description and performance of CERES-Wheat a useroriented wheat yield model. USDAARS-SR Grassland Soil and Water Research Laboratory. Temple RX, 159_/175.

Rosenzweig C., Iglesias A., 2003. Climate change and world food production: 1. Developing functions for impact assessment. 2. World food supply under several IPCC SRES scenarios. Goddard Institute for Space Studies, Special Report, New York, USA.

Roudier P., Sultan B., Quirion P., Alexis Berg A., 2011. The impact of future climate change on West African crop yields: What does the recent literature say? Global Environmental Change 21: 1073-1083.

Schlenkler W., Lobell D., 2010. Robust negative effects of climate change on African agriculture. Environ. Res. Lett. 5: 014010 (8pp).

Schlesinger M. E. Zhao Z. C., 1989. "Seasonal Climate Changes Induced by Doubling $\mathrm{CO}_{2}$ as Simulated by the OSU Atmospheric GCM Mixed Layer Ocean Model." J. Climate 2: 459-495.

Seo S.N., Mendelson R., 2008. A Structural Ricardian Analysis of Climate Change Impacts and Adaptations in African Agriculture. Policy Research Working Paper 4603. World Bank. Washington DC. USA.

Stockle C.O., Nelson R.L., 2000. Cropsyst User's manual (Version 3.0). Biological Systems Engineering Dept., Washington State University, Pullman, WA.

Tadross M., Suarez P., Lotsch A., Hachigonta S., Mdoka M., Unganai L., Lucio F., Kamdonyo D., Muchinda M., 2009. Growing-season rainfall and scenarios of future change in southeast Africa: implications for cultivating maize. Climate Research 40: 147-161. 
Thornton P. K., Jones P. G., Alagarswamy A. \& Andresen J., 2009. Spatial variation of crop yield responses to climate change in East Africa. Global. Environmental Change 19: 54-65.

Thornton P.K., Jones P.G., Ericksen P.J., Challinor A.J., 2011. Agriculture and food systems in sub-Saharan Africa in a $4{ }^{\circ} \mathrm{C}+$ world. Phil. Trans. R. Soc. 369:117-136.

Tubiello F. N., Ewert F., 2002. Modeling the effect of elevated $\mathrm{CO}_{2}$ on crop growth and yield: A review. Eur. J. Agr. 18: 57-74.

Twomlow S., Mugabe F.T., Mwale M., Delve R., Nanja D., Carberry P., Howden M., 2008. Building adaptive capacity to cope with increasing vulnerability due to climatic change in Africa - A new approach. Physics and Chemistry of the Earth 33: 780-787.

Walker N.J., Schulze R.E., 2006. An assessment of sustainable maize production under different management and climate scenarios for smallholder agro-ecosystems in KwaZulu-Natal, South Africa. Physics and Chemistry of the Earth 31: 995-1002.

Washington W., Weatherly J., Meehl G., Semtner A., Bettge T., Craig A., Strand W., Arblaster J., Wayland V., James R., Zhang Y., 2003. "Parallel Climate Model (PCM): Control and Transient Scenarios.” Climate Dynamics 16: 755-774.

White J.W., Hoogenboom G., Kimball B.A., Wall G.A., 2011. Methodologies for simulating impacts of climate change on crop production. Field Crops Research 124: 357-368

Ziervogel G., Cartwright A., Tas A., Adejuwon J., Zermoglio F., Shale M., Smith B., 2008. Climate change and adaptation in African agriculture. Prepared for Rockefeller Foundation. Stockholm Environment Institute. 


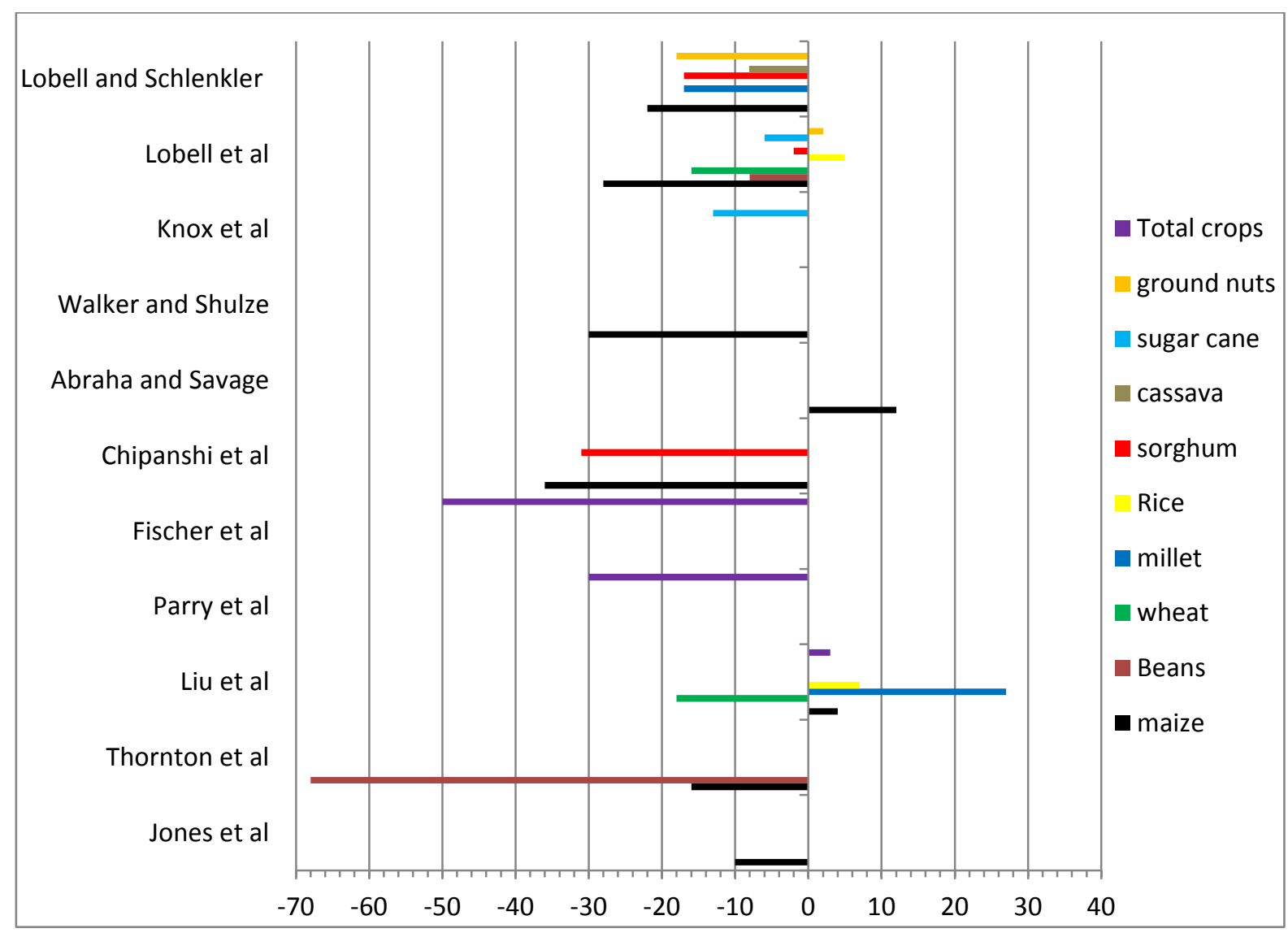

Fig. 1. Reported highest percentage yield changes per study and crop using process based and statistical methods. 


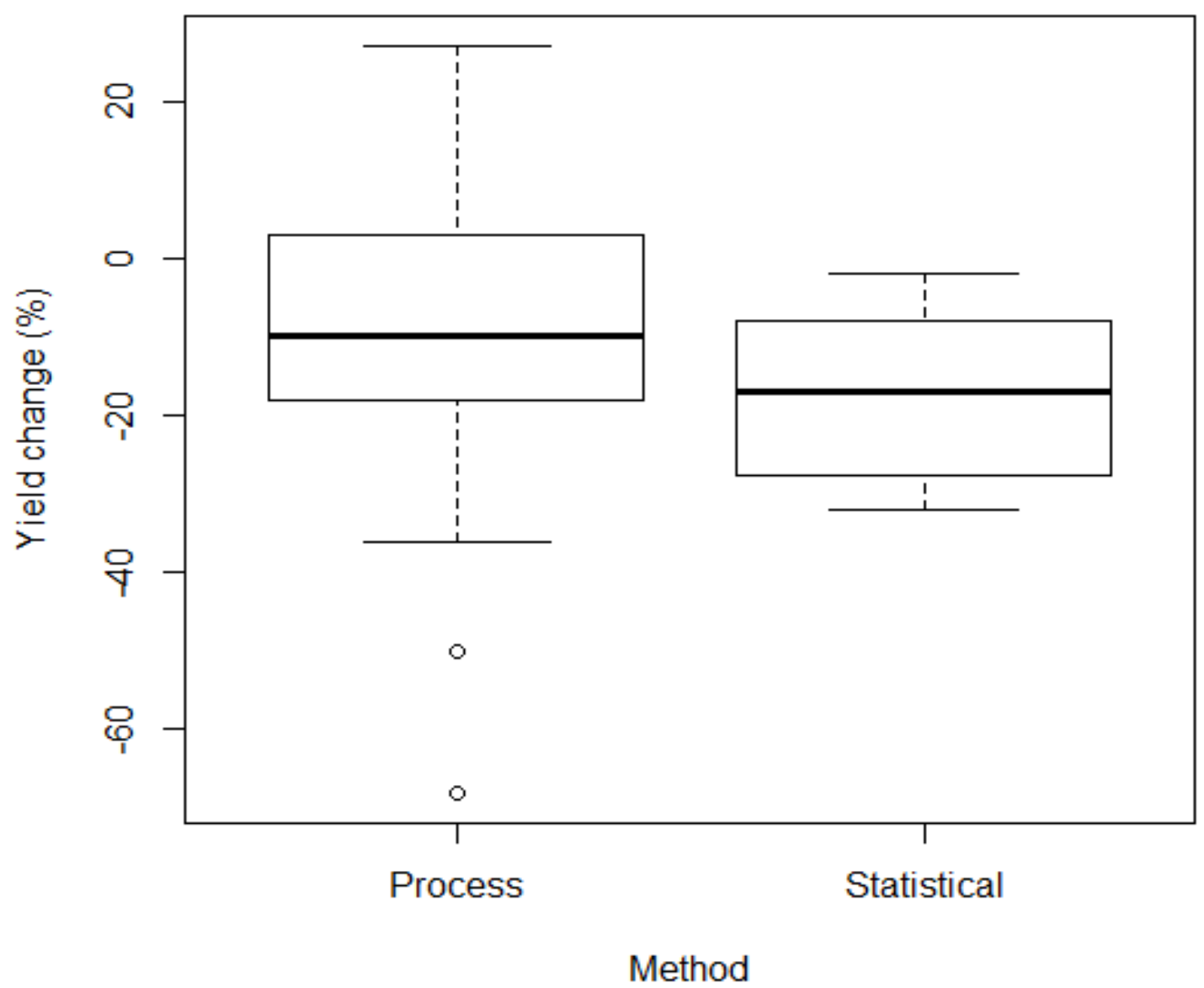

Fig. 2. Projected yield variation for all crops and periods by method of research 


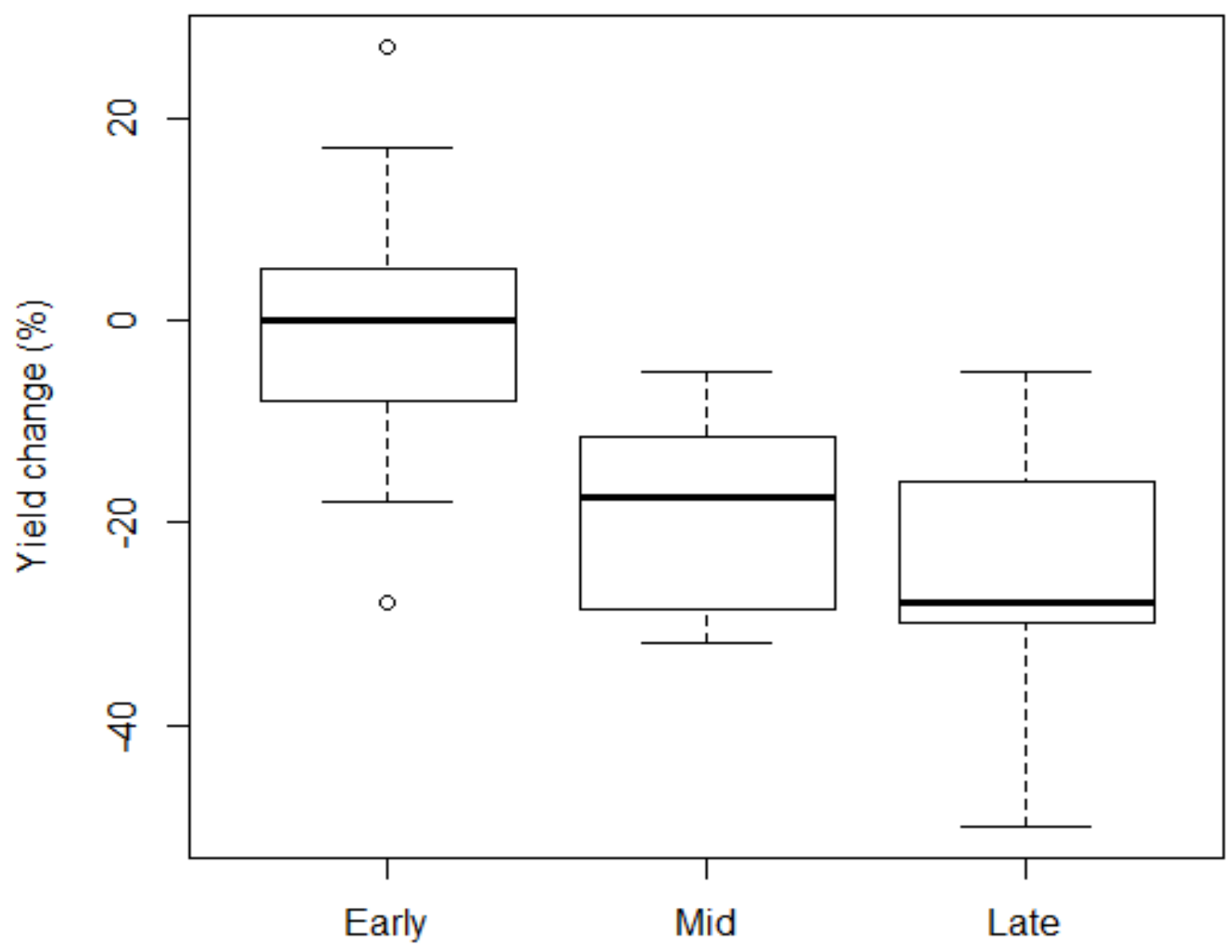

Period of 21st Century

Fig. 3. Projected yields for the 21st century: Early (2020-2039), Mid (2040-2069) and Late century (2070-2100) for all crops and methods projecting yield change (processbased and statistical) 


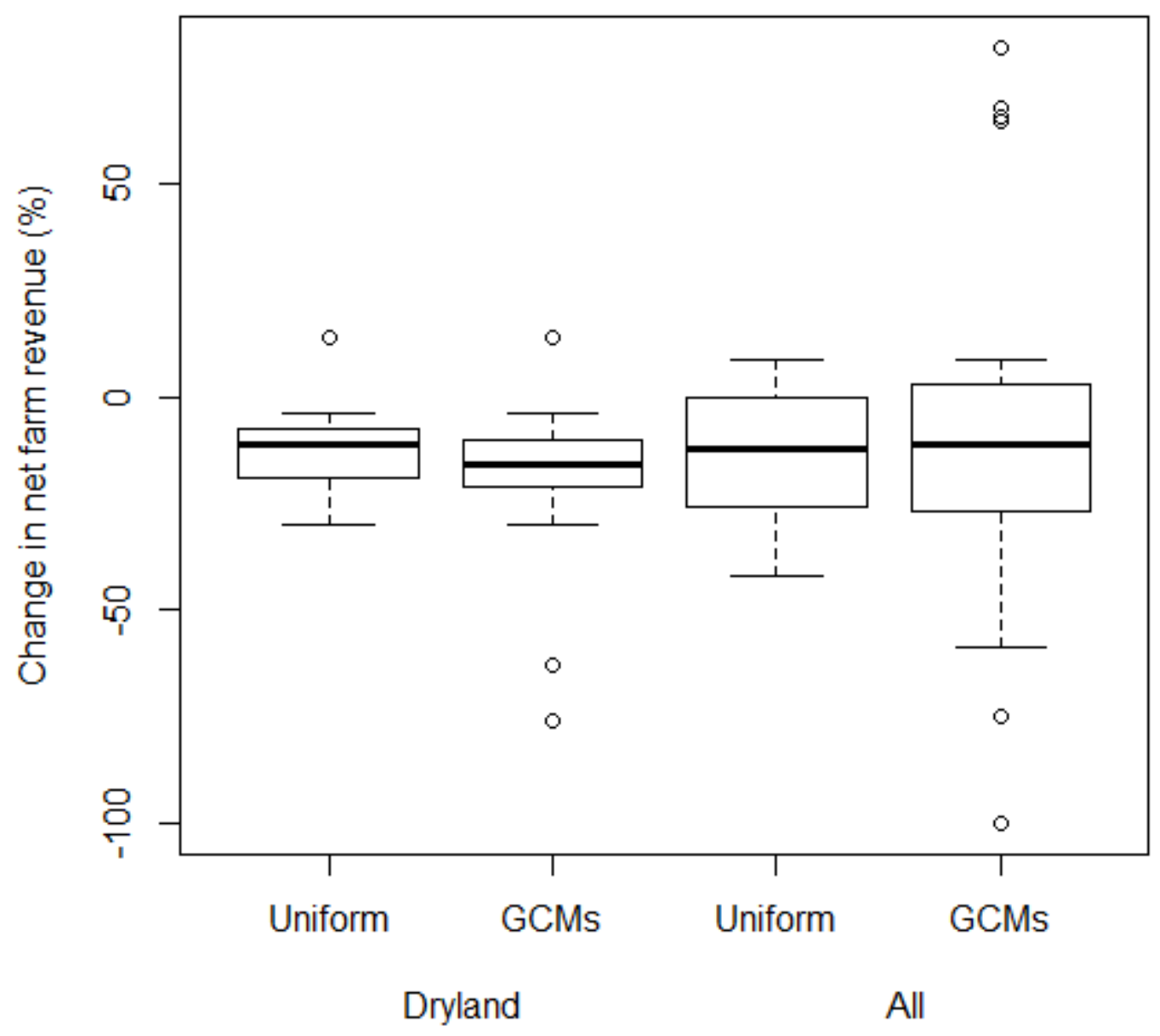

Fig. 4. Projected change in farm net revenue in all farms and dryland for the $21^{\text {st }}$ century under uniform and GCMs scenarios based on the Ricardian approach. 
Table. 1. Summary of projected temperature $\left({ }^{\circ} \mathrm{C}\right)$ changes per SRES scenario (B1, B2, A1B, A1T, A2, A1FI) by the end of the $21^{\text {st }}$ century.

\begin{tabular}{ccccccc}
\hline & B1 & B2 & A1B & A1T & A2 & A1FI \\
\hline Temperature $\left({ }^{\circ} \mathbf{C}\right)$ & $\mathbf{+ 1 . 8}$ & $\mathbf{+ 2 . 4}$ & $\mathbf{+ 2 . 8}$ & $\mathbf{+ 2 . 4}$ & $\mathbf{+ 3 . 4}$ & $\mathbf{+ 4 . 0}$ \\
& $(1.1-2.9)$ & $(1.4-3.8)$ & $(1.7-4.4)$ & $(1.4-3.8)$ & $(2.0-5.4)$ & $(2.4-6.4)$
\end{tabular}


Table. 2. Future projections of climate in Africa by the end of the $21^{\text {st }}$ century. Output from 21 GCMs (IPCC, 2007). Highlighted are changes of significance to crops in SA.

\begin{tabular}{|c|c|c|c|c|c|c|c|}
\hline \multirow[t]{2}{*}{ Region } & \multirow[t]{2}{*}{ Season } & \multicolumn{3}{|c|}{ Temperature change } & \multicolumn{3}{|c|}{ Rainfall change $(\%)$} \\
\hline & & Min & Mean & Max & Min & Mean & $\operatorname{Max}$ \\
\hline \multirow[t]{5}{*}{ Sahel } & $\mathrm{DJF}$ & 2.4 & 3.2 & 5 & -47 & -18 & 31 \\
\hline & MAM & 2.3 & 3.6 & 5.2 & -42 & -18 & 13 \\
\hline & JJA & 2.6 & 4.1 & 5.8 & -53 & -4 & 74 \\
\hline & SON & 2.8 & 3.7 & 5.4 & -52 & 6 & 64 \\
\hline & Annual & 2.6 & 3.6 & 5.4 & -44 & -6 & 57 \\
\hline \multirow[t]{5}{*}{ West Africa } & DJF & 2.3 & 3 & 3.5 & -16 & 6 & 23 \\
\hline & MAM & 1.7 & 3.5 & 3.6 & -11 & -3 & 11 \\
\hline & JJA & 1.5 & 3.3 & 3.7 & -18 & 2 & 13 \\
\hline & SON & 1.9 & 3.3 & 3.7 & -12 & 1 & 15 \\
\hline & Annual & 1.8 & 3.3 & 3.6 & -9 & 2 & 13 \\
\hline \multirow[t]{5}{*}{ East Africa } & DJF & 2 & 3.1 & 3.4 & -3 & 13 & 33 \\
\hline & MAM & 1.7 & 3.2 & 3.5 & -9 & 6 & 20 \\
\hline & JJA & 1.6 & 3.4 & 3.6 & -18 & 4 & 16 \\
\hline & SON & 1.9 & 3.1 & 3.6 & -10 & 7 & 38 \\
\hline & Annual & 1.8 & 3.2 & 3.4 & -3 & 7 & 25 \\
\hline \multirow[t]{5}{*}{ Southern Africa } & DJF & 1.8 & 3.1 & 3.4 & -6 & 0 & 10 \\
\hline & MAM & 1.7 & 3.1 & 3.8 & -25 & 0 & 12 \\
\hline & JJA & 1.9 & 3.4 & 3.6 & -43 & -23 & -3 \\
\hline & SON & 2.1 & 3.7 & 4 & -43 & -13 & 3 \\
\hline & Annual & 1.9 & 3.4 & 3.7 & -12 & -4 & 6 \\
\hline
\end{tabular}


Table 3. Reviewed studies and tools applied for crop response projections for each area, crop and time period covered. See Table 1 for simulated emissions scenarios descriptions.

\begin{tabular}{|c|c|c|c|c|c|c|c|c|}
\hline Study & Climate model & Crop model & $\begin{array}{l}\text { Simulated } \\
\text { scenarios }\end{array}$ & $\begin{array}{c}\text { Area } \\
\text { coverage }\end{array}$ & $\begin{array}{l}\text { Time } \\
\text { period }\end{array}$ & Crops covered & $\begin{array}{c}\text { Adaptation } \\
?\end{array}$ & $\begin{array}{c}\mathrm{CO}_{2} \\
\text { Effect? }\end{array}$ \\
\hline $\begin{array}{l}\text { Jones and Thornton } \\
(2003)\end{array}$ & HadCM2 & $\begin{array}{l}\text { CERES- } \\
\text { maize }\end{array}$ & N/A & $\begin{array}{l}\text { SSA \& Latin } \\
\text { America }\end{array}$ & Mid & Maize & No & No \\
\hline $\begin{array}{l}\text { Chipanshi et al. } \\
\text { (2003) }\end{array}$ & CCC, OSU, & DSSAT & $+2{ }^{\circ} \mathrm{C},+3{ }^{\circ} \mathrm{C}$ & Botswana & N/A & Maize and Sorghum & No & Yes \\
\hline Parry et al. (2004) & HadCM3 & $\begin{array}{l}\text { CERES and } \\
\text { SOYGRO }\end{array}$ & $\begin{array}{c}\text { A1FI, A2, B1, } \\
\text { B2 }\end{array}$ & Global & $\begin{array}{l}\text { Early, } \\
\text { Mid, } \\
\text { Late }\end{array}$ & $\begin{array}{c}\text { Maize, wheat, rice, } \\
\text { soybean }\end{array}$ & Partially & Yes \\
\hline $\begin{array}{l}\text { Gbetibouo and } \\
\text { Hassan (2005) }\end{array}$ & Uniform scenarios & Ricardian & $\begin{array}{l}-5 \%,-20 \% \\
+2{ }^{\circ} \mathrm{C},+3{ }^{\circ} \mathrm{C}\end{array}$ & South Africa & Late & All major crops & Yes & No \\
\hline $\begin{array}{l}\text { Fischer et al. } \\
(2005)\end{array}$ & $5 \mathrm{GCMs}$ & AEZ model & $\begin{array}{l}\text { A1FI, A1B, A2, } \\
\text { B1, B2 }\end{array}$ & SSA & Late & All cereals & Partially & Yes \\
\hline Walker and & C-CAM, Uniform & CERES- & $-10 \%,+10 \%$ & South Africa & Late & Maize & Yes & Yes \\
\hline
\end{tabular}




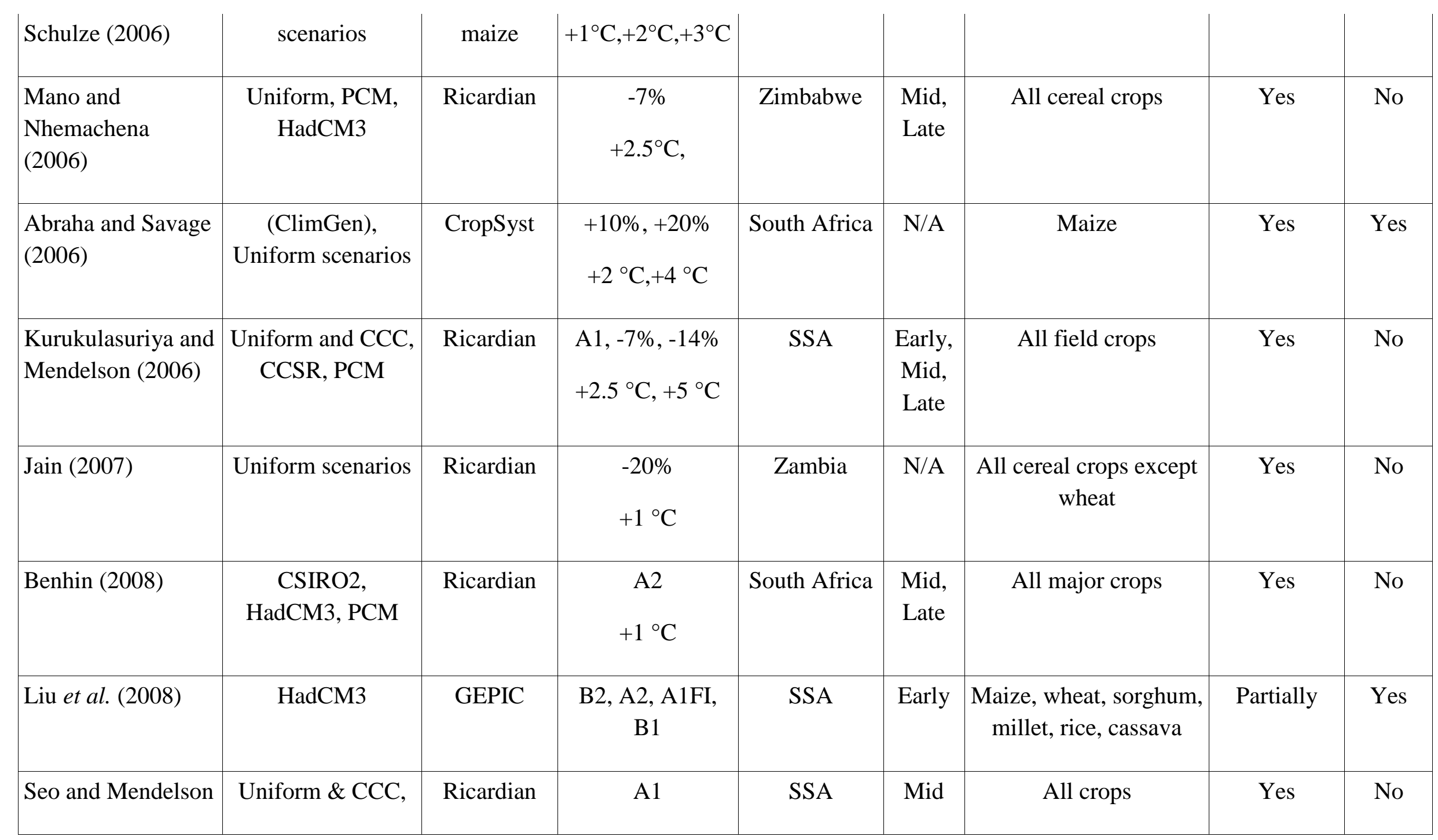




\begin{tabular}{|c|c|c|c|c|c|c|c|c|}
\hline (2008) & CCSR, PCM & & & & & & & \\
\hline Lobell et al. (2008) & $20 \mathrm{GCMs}$ & Statistical & $\begin{array}{c}-10 \%,+5 \% \\
+1{ }^{\circ} \mathrm{C}\end{array}$ & Global & Early & $\begin{array}{l}\text { Maize, wheat, sorghum, } \\
\text { rice, cassava, soybean, } \\
\text { groundnut, sugar cane }\end{array}$ & No & No \\
\hline $\begin{array}{l}\text { Kurukulasuriya and } \\
\text { Mendelson (2008) }\end{array}$ & $\begin{array}{c}\text { Uniform, PCM, } \\
\text { CCC }\end{array}$ & Ricardian & $+1{ }^{\circ} \mathrm{C},+1 \mathrm{~mm}$ & SSA & Late & Multiple crops & Yes & No \\
\hline $\begin{array}{l}\text { Nhemachena } \\
(2009)\end{array}$ & $\begin{array}{c}\text { Uniform, PCM, } \\
\text { CCC }\end{array}$ & Ricardian & $\begin{array}{c}\mathrm{A} 1,+2.5{ }^{\circ} \mathrm{C}, \\
+5^{\circ} \mathrm{C},-7 \%,-14 \%\end{array}$ & SSA & Late & All field crops & Yes & No \\
\hline Knox et al. (2010) & HadCM3 & CANEGRO & $\mathrm{A} 2, \mathrm{~B} 2$ & Swaziland & Mid & sugarcane & Yes & Yes \\
\hline $\begin{array}{l}\text { Schlenkler and } \\
\text { Lobell (2010) }\end{array}$ & 16 GCMs & Statistical & A1B & SSA & Mid & $\begin{array}{c}\text { Maize, Sorghum, } \\
\text { millet, cassava, ground } \\
\text { nuts. }\end{array}$ & No & No \\
\hline $\begin{array}{l}\text { Thornton et al. } \\
(2011)\end{array}$ & 14 GCMs & DSSAT & $\begin{array}{c}\mathrm{A} 1 \mathrm{~B}, \mathrm{~A} 2, \mathrm{~B} 1 \\
+5{ }^{\circ} \mathrm{C}\end{array}$ & SSA & Late & Maize, beans & No & No \\
\hline
\end{tabular}

SSA-sub-Sahara Africa

HadCM2-UK Hadley Centre's second generation climate model (Johns et al., 1997) 
HadCM3-UK Hadley Centre's third generation climate model (Johns et al., 2003)

CCC-Canadian Climate Centre model (Boer et al., 2000)

CCSR-Centre for Climate Systems Research (Emori et al., 1999)

C-CAM-Conformal-Cubic Atmospheric Model (McGregor and Dix, 2001)

PCM-Parallel Climate Model (Washington et al., 2000)

CSIRO2-Commonwealth Scientific and Industrial Research Organisation (Gordon et al., 2002)

OSU-Oregon State University model (Schlesinger and Zhao, 1989)

AEZ-Agro-Ecological Zone model (Fischer et al., 2002)

CropSyst-Cropping Systems simulation model (Stockle and Nelson, 2000)

CERES-Crop Estimation through Resource and Environment Synthesis (Ritchie and Otter, 1984)

DSSAT-Decision Support System for Agro-technology Transfer: Within it is Ceres-maize, CANEGRO, SOYGRO (Jones et al., 2003)

GEPIC-An Environmental Policy Integrated Climate (EPIC) model with a Geographical Information System (GIS) (Liu et al., 2007) 
